ELORE (ISSN 1456-3010), vol. 20 - 1/2013.

Julkaisija: Suomen Kansantietouden Tutkijain Seura ry.

[http://www.elore.fi/arkisto/1_13/kaski.pdf]

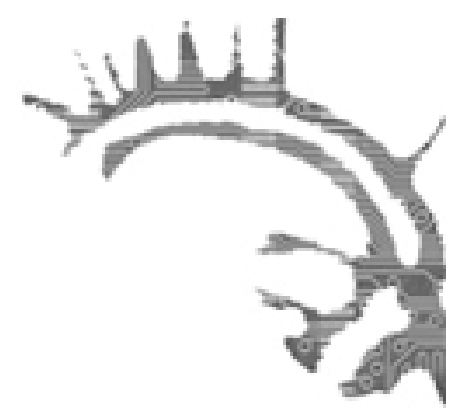

\title{
ArtikKeli
}

\section{IHMISEN JA ELÄIMEN SUHTEESTA VARHAISESSA KREIKKALAISESSA AJATTELUSSA}

\author{
Liisa Kaski
}

Ehkä kysyt, mistä syystä Pythagoras kieltäytyi syömästä lihaa. Minä puolestani ihmettelen, minkä taipumuksen vuoksi ja minkä mielentilan vallassa tai minkä päättelyn nojalla ihminen ensimmäisen kerran tahrasi suunsa vereen ja kosketti huulillaan kuolleen eläimen lihaa. Miksi hän asetti tarjolle kuolleiden ruumiita, elävien varjokuvia, ja kutsui sen lisäksi ruoaksi ja ravinnoksi ruumiinosia, jotka vasta äsken olivat mylvineet, kiljuneet, liikkuneet ja mulkoilleet. [...]

$[\mathrm{M}] \mathrm{ikä} \mathrm{ja} \mathrm{millainen} \mathrm{raivo} \mathrm{ja} \mathrm{kiihko} \mathrm{ajaa} \mathrm{teitä} \mathrm{nyt} \mathrm{tahraamaan} \mathrm{itsenne} \mathrm{mur-}$ halla, kun teillä on paljon enemmän kuin välttämättä tarvitsette? Miksi väitätte ilman perusteita, ettei maa kykene elättämään teitä? Miksi häpäisette lainlaatija Demeteriä ja solvaatte viininviljelyn suojelijaa, rakastettavaa Dionysosta, ikään kuin he eivät antaisi teille riittävästi antimiaan? Ettekö häpeä tahrata myös viljellyn ruokanne, kun liitätte siihen murhan?

(Plutarkhos 2004, 9-12.)

Ajanlaskumme ensimmäisen vuosisadan lopulla elänyt kreikkalainen filosofi Plutarkhos jätti jälkeensä joukon eläinten älykkyyttä, tunteita, arvoa ja oikeuksia pohtivia kirjoituksia. Yksi näistä on painokas puheenvuoro kasvissyönnin puolesta; toisessa punnitaan maa- ja merieläinten henkisen kyvykkyyden eroja suhteessa toisiinsa ja ihmiseen. Kolmas teksti antaa äänen siaksi noidutulle miehelle, joka vakuuttavin argumentein perustelee Odysseukselle, kreikkalaisista sankareista nokkelimmalle, miksi valitsee mieluummin 
hyveellisen elämän sikana kuin paluun ihmisen hahmoon. ${ }^{1}$ Kaikissa kolmessa puututaan sekä suoraan että epäsuorasti myös ihmisten oikeuksiin ja velvollisuuksiin suhteissamme muihin eläimiin.

Plutarkhos on parhaiten säilynyt mutta vain yksi esimerkki antiikin filosofeista, jotka käsittelivät ihmisen ja muiden lajien suhdetta mahdollisen tasavertaisuuden ja oikeudenmukaisuuden ( $\delta i \kappa \eta)$ näkökulmasta. Esimerkiksi lihansyönnin eettisen ongelmallisuuden pohdinta on jatkumo, joka antiikin filosofian piirissä ulottuu Pythagoraasta (n. 570-n. 495 eKr.) ja Empedokleesta (500-400-lukujen taite) peripateetikko Theofrastokseen (n. 371-287 eKr.), uuspythagoralaiseen Apollonios Tyanalaiseen (ajanlaskun taite-1. vuosisata), Plutarkhokseen (n. 45-125 jKr.) ja uusplatonikko Porfyriokseen (234-n. $305 \mathrm{jKr}$.).

Olivatko nämä filosofit aikansa toisinajattelijoita, vallitsevan näkemyksen haastajia? Vai oliko kreikkalaisessa ajattelussa ja maailmankuvassa laajemminkin jotain, mikä mahdollisti tai jopa tuotti heidän radikaaleilta vaikuttavat kannanottonsa? Onko sitä myöten eurooppalaisessa ajattelussa ituja, jotka jäivät versomaan piiloon ja joita voisimme kasvattaa nyt?

Artikkeli jakaantuu kahteen osaan. Aluksi käyn hieman läpi sitä, millä tavoin eläinkysymyksiä käsittelevät filosofit argumentoivat eläinten tappamisesta pidättäytymisen puolesta. Esimerkeikseni olen valinnut Plutarkhoksen ja Empedokleen - edellisen siksi, että hän on tarinaperinnettä laajalti hyödyntävänä kirjoittajana kiinnostava ajattelija erityisesti folkloristin kannalta, ja jälkimmäisen siksi, että hän on varhaisin tutkimaani eläinteemaan liittyviä fragmentteja jälkeensä jättänyt filosofi ja siten ajallisesti lähimpänä sitä runo-, myytti- ja riittiaineistoa, jota artikkelini jälkimmäisessä osassa tarkastelen.

Plutarkhoksen ja Empedokleen eläintekstien tarkastelun jälkeen yritän hahmottaa heidän ja muiden kreikkalaisten eläinmyönteisten ajattelijoiden taustalla vaikuttavaa kulttuuria, sen kollektiivisesti jaettuja merkityksiä, käsitteitä ja niihin piiloutuvia arvoja tutkimalla mahdollisimman lähellä äänenvaraista kulttuuria syntyneen runouden eläinkuvaa ja -metaforiikkaa. Kreikan oloissa tämä tarkoittaa ns. arkaaista kautta 700-luvulta noin vuoteen $500 \mathrm{eKr}$. Tältä aikakaudelta on peräisin varhaisin tunnettu kreikaksi kirjoitettu runous. Koska arkaaisenkin ajan runoutta on myöhempinä sitaatteina, antologioiden osina ja käsikirjoituksina säilynyt suhteellisen paljon, joudun rajaamaan käsittelyni muutamaan eläinteemaan ja runoesimerkkiin. Tarkasteltavanani on fragmentti spartalaiselta kuorolyyrikko Alkmanilta (600-luku eKr.) sekä otteita homeerisesta runoudesta.

Arkaaisen runouden rinnalla ja erottamattomana osana pohdin kreikkalaisen mytologian välittämää kuvaa eläimistä, erityisesti eläimen ja jumalan suhdetta. Kysymys on antiikin ihmishahmoisiin jumaliin kiertyvässä uskontoperinteessä hyvin monikerroksinen, ristiriitainenkin. Vaikka lähtökohtaisesti vaikuttaa siltä, että antroposentrinen maailmankuva on Kreikassa jo varhain nostanut ihmisen taiteen, uskonnon ja ajattelun keskipisteeksi, uskonnollisissa rituaaleissa eläimillä oli keskeinen osa. Tutuin ja tutkituin rooli on uhrieläimillä, mutta vähemmän tunnettuja ovat rituaalit, joissa eläin, tai eläinmetafora, on itse aktiivinen toimija. Esimerkkeinäni ovat Alkmanin runon kontekstina oleva spartalaisten nuorten neitojen rituaali sekä attikalaistyttöjen kasvatukseen liittynyt karhuriitti Artemis Brauronian pyhäkössä Attikan itärannikolla. 
Liisa Kaski: Ihmisen ja eläimen suhteesta varhaisessa kreikkalaisessa ajattelussa

\section{Plutarkhos Ja eläinten Oikeudet?}

Arkiajattelussa yleisesti esiintyvän olettamuksen mukaan eläinten oikeuksista puhuminen tai niiden pohtiminen on täysin moderni, jopa jälkimoderni ilmiö. Kuten Gary Steiner historiallisesti kattavassa tutkimuksessaan eurooppalaisen eläimiä koskevan ajattelun kehityksestä toteaa, antiikin kreikkalainen filosofia kuitenkin tuotti sekä oivaltavia näkemyksiä että kauaskantoisia debatteja aiheen tiimoilta (Steiner 2005, 36-37; ks. myös Sorabji 1993, 156-157). Antiikin moraalifilosofia ei jäsenny ensisijaisesti oikeuksien ja velvollisuuksien, vaan esimerkiksi hyveiden pohtimisen varaan, ja vaikkapa Plutarkhoksen pakottaminen modernin eläinoikeuskeskustelun käsitteistöön vain kaventaisi hänen monipuolisen ajattelunsa antia tälle keskustelulle. Nykyaikaista eläinkeskustelua silmälläpitäen ja edellä mainitun harhakäsityksen korjaamiseksi pidän kuitenkin tämän artikkelin puitteissa mielekkäänä nostaa Plutarkhoksen ajattelusta esiin nimenomaan eläinten oikeuksien käsitteeseen liittyviä tai sitä sivuavia esimerkkejä.

Plutarkhosta tutkinut ja kääntänyt Sven-Tage Teodorsson $(2007,12-13)$ tiivistää Plutarkhoksen argumentit eläinten tappamisesta pidättäytymisen puolesta seuraavasti. 1) Ihmiset ja muut eläimet ovat biologisesti samankaltaisia: muistutamme toisiamme sekä fyysisesti että henkisesti, ja myös muut eläimet ilmaisevat ja ilmentävät sekä älyä että tunteita käytöksellään. 2) Erot eri eläinten älykkyydessä, tunne-elämässä ja henkisessä kyvykkyydessä ovat pikemminkin yksilöiden kuin lajien välisiä. Monissa tapauksissa muiden eläinten toiminta on jopa esikuvallista ihmiseen nähden (ks. erityisesti Plutarkhos, Gryllos, 987b-992d.2.) 3) Ihmisen tapaan myös muilla eläimillä on oikeus omaan elämäänsä. 4) Ihmisen ruumiinrakenne osoittaa, ettei ihminen ole petoeläin. Niinpä lihansyönti on ihmisen luonnon vastaista ja tuhoaa hänen fyysisen terveytensä. Lihansyönti haittaa myös ihmisen henkisiä toimintoja ja estää siten ihanteellisen ihmisyyden toteuttamista. 5) Muiden eläinten tappaminen raaistaa ihmisen ja saa hänet toimimaan väkivaltaisesti myös toisia ihmisiä kohtaan. Vastaavasti lempeys eläimiä kohtaan tuottaa lempeyttä myös ihmistenvälisissä suhteissa. 6) On mahdollista, että sielu siirtyy toiseen eläimeen yhden elämän päättyessä. Kannibalismi on kreikkalaisessa ajattelussa hirvittävimpiä kuviteltavissa olevia taburikkomuksia (ks. esim. Wright 1995, 284) - siksi on varovaisuusperiaatteen nojalla parempi pidättäytyä toisten eläinten syömisestä, vaikkei sielunvaellukseen itse uskoisikaan.

Antiikin eläinkeskustelun tuntemuksen kannalta on sääli, ettei Plutarkhoksen Lihansyönnistä-esseen loppuosa ole säilynyt meidän päiviimme asti. Säilynyt teksti nimittäin katkeaa näin: "Tutkikaamme nyt sitä, emmekö ole tehneet oikeudellista sopimusta ${ }^{3}$ eläinten kanssa. Älkäämme tehkö tätä millään keinotekoisella tai monimutkaisella tavalla, vaan kohdistakaamme huomiomme omiin tunteisiimme ja käyden sisäistä, inhimillistä vuoropuhelua ja punniten..." (Plutarkhos 2004, 33; kursivointi L.K.)

Plutarkhos sivuaa oikeudenmukaisuuden kysymystä myös De sollertia -tekstissä:

[M] eidän, jotka pidämme elämäntapaamme sivistyneenä ja inhimillisenä, on vaikea sanoa, mitä meille jäisi kaikista monimutkaisista toimistamme maalla ja merellä - mikä ilmaa koskeva taito ${ }^{4}$, mikä hienostunut ruokavalio - jos 
oppisimme kohtelemaan vahingoittamatta ja huomioonottaen kaikkia eläimiä, ikään kuin rationaalisina ja samanheimoisina. Lääkettä tai parannusta tähän ongelmaan ei ole: joko luovumme tähänastisesta elämäntavastamme tai luovumme oikeudenmukaisuudesta [...].

(Plutarkhos, De sollertia 964a-b; suomennos Tua Korhonen.)

Dialogimuotoisessa tekstissä henkilöhahmojen keskustelu kuitenkin polveilee aiheesta eteenpäin siten, että lopputulos - sikäli kuin antiikin filosofialle tyypillinen dialogimuoto oikeuttaa puhumaan "lopputuloksesta" missään jäännöksettömässä ja lukkoonlyödyssä merkityksessä - tuntuisi poikkeavan siitä, mihin Lihansyönnistä-essee kadonneessa lopussaan kenties päätyi. De sollertian henkilöhahmot nimittäin siirtyvät keskustelemaan ensin Hesiodoksen, Empedokleen, Herakleitoksen ja Pythagoraan käsityksistä, sitten eläinten hyväksikäytön mahdollisesta oikeutuksesta ja nimenomaan julman hyväksikäytön tuomittavuudesta (Plutarkhos, De sollertia 964b-965b). Eläinten oikeuksiin sellaisenaan, tai kysymykseen meitä velvoittavasta oikeudenmukaisuudesta jonakin eläimistä itsestään lähtöisin olevana, Plutarkhos ei enää teksteissään palaa.

Plutarkhoksen ja nykyaikaisen eläinoikeusajattelun välillä on lähinnä kaksi merkittävää eroa: Plutarkhos korostaa ihmisen ja muiden eläinten kumppanuutta ja tukee näin ollen myös ajatusta toisenlajisista eläimistä ihmisen työtovereina (esim. Plutarkhos, De sollertia 969e-970d) ja hyväksikäytön kohteina, edellyttäen että "hyväksikäyttö" on sekä väkivallatonta että tarpeiden vuoksi perusteltavissa (Plutarkhos, De sollertia 964f-965b). Toiseksi Plutarkhos vetoaa ihmisen spirituaalisuuteen (esim. Plutarkhos, Lihansyönnistä 995d-996c) antiikin holistisen terveyskäsityksen mukaisesti: filosofinen mieli elää terveessä ruumiissa, ja ruumista hairahduttavat virheet, kuten epäsopiva ravinto, estävät mieltä toimimasta asianmukaisesti. Jälkimmäisen asenteen moderni eläinoikeusfilosofia yleensä ohittaa antroposentrisenä ja välineellisenä: tämän asenteen mukaan eläimiä on siis kohdeltava hyvin, jotta ihminen itse voisi hyvin, eikä niiden itsensä takia (esim. Singer 1990, 241; Regan 2001, 4-18; Aaltola 2006, 76-77; eläinoikeusdiskurssin piilevästä antroposentrisyydestä ks. Steiner 2005, 6-29). Viimeistään valistusajalta lähtien myös ihmisen hengellisyyteen vetoaminen moraalifilosofian perustana on kyseenalaistettu.

Ylläolevassa lainauksessa Plutarkhoksen henkilöhahmon suusta kuitenkin pääsee mie-

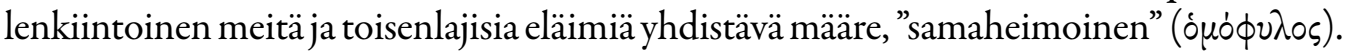
Kantana oleva sana fyle ( $\phi \nu \lambda \dot{\eta})$ viittaa yleensä (ihmisten) heimoon, klaaniin, yhteiseen verenperimään ja syntyperään, ja vaikka on mahdotonta sanoa, missä määrin metaforisesti Plutarkhos sitä tässä käyttää, sanavalinta on kiinnostava. Jonkinlainen kaikkia lajeja yhdistävä yhteinen syntyperä oli nimittäin keskeinen ajatus myös Plutarkhoksen varhaisella edeltäjällä, esisokraatikko Empedokleella.

\section{EMPEDOKLES JA KULTAKAUSI}

Usein kreikkalaisen filosofian huipentumana ajatellaan Platonia (427-347 eKr.) ja/ tai Aristotelesta (384-322 eKr.), jotka kiistatta jättivät jälkipolviin, eurooppalaiseen 
kulttuuriin ja kristinuskoon syvän jäljen. Klassisen taiteen kultakausi ja monet tieteellisesti, kulttuurisesti ja poliittisesti merkittävät ilmiöt, esimerkiksi demokratian vakiintuminen, osuvat kuitenkin 400-luvun puolivälin eKr. paikkeille; kaksi, kolme tai neljäkin sukupolvea varhaisempaan aikaan. Platon tai hänen opettajansa ja sittemmin kirjallisen tuotantonsa päähenkilö, Sokrates, eivät syntyneet filosofiseen tyhjiöön. "Klassisen kultakauden" ajattelun ilmauksia onkin etsittävä Platonin dialogien sijaan vaikkapa Sofokleen tragedioista, Herodotoksen etnografis-historiallisista tarinoista ja ns. esisokraatikkojen filosofiasta.

Viimeksi mainituista Sisilian Akragaksessa (nyk. Agrigento) syntynyt Empedokles (n. 490-430 eKr.) on tuotannoltaan parhaiten säilynyt, joskaan ei välttämättä tunnetuin, ja viimeinen klassisen kauden filosof, joka kirjoitti teoksensa runomuodossa. Hänen tiede-

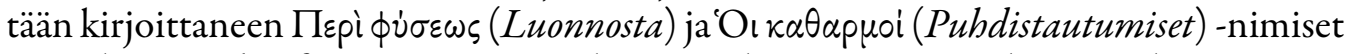
runoelmat, joiden fragmentteja on säilynyt ja rekonstruoitu myöhempien kirjoittajien, esimerkiksi juuri Plutarkhoksen, teksteistä.

Empedokles ei toki itse ajatellut elävänsä kreikkalaisen maailman kultakautta, vaikka oleskelikin myös kukoistavassa Ateenassa ja Peloponnesoksella. Myytti menneestä kultaajasta oli sen sijaan hänen ajatteluunsa vahvasti vaikuttanut yleiskreikkalainen idea, jonka varhaisin kirjallinen esitys on Hesiodoksen Työt ja päivät -runoelmassa (luultavasti 700-luvulta eKr.) ja joka tulee esiin mm. orfilaisuudessa, Platonilla ja uusplatonisteilla sekä roomalaisella Ovidiuksella ( $43 \mathrm{eKr}$ - $17 / 18$ jKr.), joka välitti kreikkalaista mytologista perinnettä länteen. Myyttisen kulta-ajan ihmiset elivät sopusoinnussa toistensa, muiden eläinten ja jumalten kanssa ja söivät luonnollisesti kasvisruokaa, jota paratiisillinen maa heille vaivatta tarjosi.

Empedokleen käsitys kultakaudesta ja sen päättymiseen johtaneesta syystä oli seuraavanlainen:

Eikä heillä ollut Aresta jumalana eikä Kydoimosta, ei kuningas Zeusta, ei Kronosta eikä Poseidonia, vaan kuningatar Kypris. ${ }^{5}$ Häntä lepyttivät he kunnioittavin lahjoin, piirretyin eläimin, taiturillisin tuoksuvoitein sekä sekoittamattoman mirhan ja suitsukepihkan uhrein, ja vuodattaen maahan vaalean hunajan maljan [...] Härkien murhasta ${ }^{6}$ ei lainehtinut alttari, vaan suurin tahra ihmiselle oli tämä: riistää elämän henki ja ahmia pyhäiset raajat. [...]

He olivat kesyjä kaikki ja ihmisille suopeita, pedot sekä linnut, ja kirkkaana paloi heidän lempeytensä liekki. [...]

Voi kun ei tuhonnut minua säälimätön päivä, ennen kuin lihansyönnin viheliäisen toimen huulilleni tuumasin! [...]

Ettekö lakkaa pahoin kaikuvasta murhasta? Ettekö näe, että toinen toistanne ahmitte mielen välinpitämättömyyden takia? [...]

Siksipä vaellatte suunniltanne raskaista vastoinkäymisistä, eikä henkenne ${ }^{7}$ koskaan toivu surkeista tuskista.

(Empedokles fr. 118-120 ja 122-123; suomennos L.K.) $)^{8}$ 


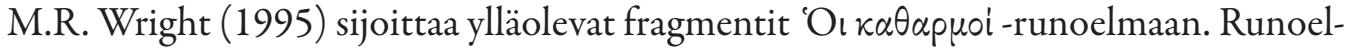
man perusideana on erilaisten puhdistautumisrituaalien kautta tavoitella tilaa, josta ihmisen hairahdukset ovat hänet karkottaneet. Runon minä on maailmassa harhaileva opettaja, kilvoittelija ja lääkäri-filosofi-maagi, luultavasti Empedokleen alter ego. Taus-

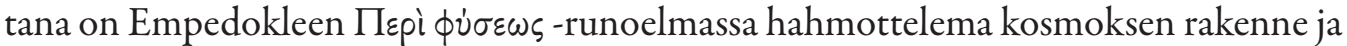
kehityshistoria sekä erilaisten elävien olentojen suhde toisiinsa elämän kokonaisuudessa. Kaikki elämä rakentuu neljästä elementistä, joista Empedokles käyttää vaihtelevasti sekä jumalten nimiä että tuleen/aurinkoon, ilmaan/taivaaseen/valoon, veteen/mereen/ sateeseen/kosteuteen ja maahan/maanalaisuuteen viittaavia substantiiveja. Elementit yhdistyvät ja erottautuvat kahden toisilleen vastakkaisen voiman, rakkaudellisuuden (filotes, Afrodite, Kypris, Harmonia jne.) ja kiistan (neikos, Ares jne.) vaikutuksesta, ja voimasuhteiden vähittäinen mutta jatkuva muutos on koko ajan käynnissä. Lisäksi kaikkea elämän kokonaisuudessa kasveista eläimiin ja jumaliin asti sitoo toisiinsa "laajoin valoin sinetöity välttämättömyyden iäinen vaade" (fr. 107, suomennos L.K.). Meidät ja kaikki muut on tehty samoista aineksista, jaamme saman elämän hengen (Wright 1995, 22-34).

Erityisesti 'Oı $\kappa a \theta \alpha p \mu o i$-runossa, josta ylläoleva lainaus on, Empedokles kuitenkin painottaa ihmisen tekoja ja niiden seurauksia; sovun ja kiistan ikuinen vuorottelu ei ole mekaanista eikä ennalta säädeltyä. Ihmisen tulee pyrkiä myötävaikuttamaan siihen, että rakkaudellisuus voittaa jalansijaa, ja tavoitella mennyttä rakkauden hallitsemaa "kultaaikaa” pidättäytymällä mm. tappamisesta ja lihansyönnistä. (Wright 1995, 57-76.)

Kuten Wright $(1995,76)$ toteaa, Empedokleen ajatusmaailma ei perusteiltaan poikkea radikaalilla tavalla muiden esisokraatikoiden kehittelemistä teorioista. Hänen ajattelussaan omana aikanaan poikkeavaa ei siis liene niinkään ollut ihmisen ja muiden eläinten kokeminen saman jatkumon osasina, vaikka veriuhrin kieltäminen ja tappamisesta pidättäytyminen radikaaleja johtopäätöksiä olivatkin. Sen sijaan poikkeavaa edeltävään eeppiseen perinteeseen nähden on toisaalta jumalten, toisaalta kasvikunnan hahmottaminen tämän saman jatkumon, saman elämänkokonaisuuden osina yhdessä eläinkunnan kanssa. (Wright 1995, 61-62.)

Tähän liittyen myös yksittäisen elämän rajat avartuvat uudelleen määriteltäviksi. Empedokles (tai hänen runominänsä) toteaa itse jo olleensa "poika ja tyttö sekä pensas ja lintu ja myös mykän meren kala" (fr. 108, suomennos L.K.; vrt. myös fr. 104). Meitä ja muita siis yhdistävät paitsi samat fyysiset rakenne-elementit, myös hahmosta toiseen vaeltava ja eri elämänmuodoista turvapaikkansa löytävä luova mieli, daimon. ${ }^{9}$

Empedokleen pääargumentti lihansyöntiä vastaan ja kaikenlajisten eläinten elämisen oikeuden puolesta ei kuitenkaan ole sielunvaellus, vaikka hänet on useimmiten liitetty sielunvaellusoppiin tukeutuvan kasvissyöntiperinteen osaksi. Pythagoralaisesti virittynyt, sielunvaellususkoon perustuva eläinten tappamisesta pidättyminen voi ainakin teoriassa perustua yksinomaan ihmisen erityisyyteen: tuo susi voi olla isoisäsi tai kuollut poikasi, siksi teet väärin vahingoittamalla sitä. Empedokleen mukaan sen sijaan eläinten tappaminen on väärin, koska me elävät olemme sukua toisillemme, samasyntyisiä ( $\sigma \dot{v} \gamma \varepsilon v \varepsilon \varsigma)$, ja sukulaisen tappaminen on vastoin "kaikkien lakia, joka katkeamatta ulottuu halki laajalti hallitsevan taivaan ja määrättömän auringonvalon ${ }^{10 "}$ - eli vastoin luonnollista oikeutta, kuten Aristoteles myöhemmin artikuloi Empedoklesta referoidessaan. (Empedokles fr. 121, suomennos L.K.; Aristoteles, Retoriikka 1373b 14-16; Balaudé 1997, 
33-41; Sorabji 1993, 151.) Rikkomalla tätä lakia ihminen asettuu maailmaa ja häntä

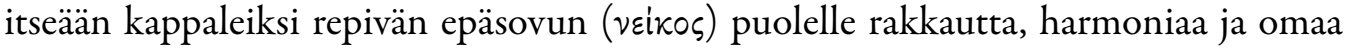
onneaan vastaan.

Empedokles on arvoituksellinen ajattelija, eikä ainoastaan fragmentaarisen säilymisensä vuoksi. Jo antiikinaikaiset kommentaattorit tulkitsivat häntä eri tavoin ja osin keskenään ristiriitaisesti. Olen edellä esitellyt niitä fragmentteja, joissa eläinten tappamisen oikeutus kielletään; taustalla olevaa laajempaa filosofista rakennelmaa hahmottelin vain viitteellisesti. Uskoakseni vaikeinta Empedokleen liittämisessä myöhempään filosofiseen perinteeseen ja nykyaikaiseen eläinkeskusteluun on se ilmaisullinen juopa, joka aukeaa hänen heksametriensä ja meidän logiikkaa tavoittelevien proosallisten lauseidemme väliin.

Pian Empedokleen jälkeen kieltä, eläintä, ihmistä ja filosofiaa alettiin ajatella, määritellä ja rajata radikaalisti toisella tavalla (ks. esim. Wolff 1997, 166-180; Sorabji 1993, 12-20; Steiner 2005, 53-77). Tätä Aristoteleen teksteihin paikantuvaa mutta jo ennen häntä alkanutta ja vasta hänen jälkeensä vakiintuvaa eläinajattelun murrosta kartoittava Steiner tekee oivallisen huomion: ihmisen erityisyyttä ja ylemmyyttä korostavissa ja eläinten rationaalisuuden kieltävissä teksteissään Aristoteles tiedostaa antropomorfisoivan ilmaisun ongelmat ja välttelee antropomorfisia kielikuvia eläimistä puhuessaan. Eläintieteellisissä teksteissään hän sen sijaan, pyrkiessään kuvaamaan eläinten olemista ja käyttäytymistä, kuvaa ihmistä yhtenä lajina muiden joukossa ja muunlajisista eläimistä puhuessaan turvautuu metaforiin. (Steiner 2005, 72.) Ehkä onkin niin, että pyrkiessään tavoittamaan toisenlajisen eläimen kokemuksen ja kuvaamaan sitä ihminen joutuu kurottelemaan kohti kielensä rajoja tai venyttämään niitä. Syntyy metaforia. Syntyy runoutta. Siirrynkin nyt tutkimaan sitä, löytyykö varhaisesta kreikkalaisesta runoudesta kaikupohjaa Plutarkhoksen ja Empedokleen kaltaisten ajattelijoiden käsityksille ihmisen suhteesta toisenlajisiin eläimiin.

\section{ArkaAisen runON Eläimet}

Arkaainen kreikkalainen runous on päällisin puolin hyvin ihmiskeskeistä. Yksi selittävä tekijä voi olla se, että varsinaista suullista kansanrunoutta kreikankielisestä antiikista ei ole säilynyt. Homeerinen sankarirunous on luonteeltaan toisenlaista kuin vaikkapa itämerensuomalainen epiikka, johon sitä usein verrataan, mutta ero ei välttämättä selity kreikkalaisen kulttuurin tai ihmisluonteen tai edes geopoliittisen aseman erolla suomalais-ugrilaiseen. Vaikka varhainen kreikkalainen runous on säilönyt äänenvaraisen runokielen elementtejä, runot kirjoitettiin ja niitä levitettiin kirjoitettuina ja ääneen luettuina tai laulettuina versioina viimeistään 500-luvulta eKr. eteenpäin, luultavasti jo muutama sata vuotta sitä ennenkin. Homeroksen jälkeinen arkaaisen ajan runous on kirjoittaen syntynyttä sana- ja laulutaidetta. Homeerisen runouden sosiaalinen konteksti, kytkös heeroskulttiin ja kirjoitustaidon tuottama kulttuurinen murros todennäköisesti selittävät, miksi tuntemamme kreikkalainen epiikka keskittyy niin voimakkaasti tietyn ihmisryhmän, aristokratian, edesottamuksiin. (Ks. esim. Havelock 1963, 92-95; Hadzisteliou Price 1979, 219-228; Nagy 1995, 165-174; Ong 1967, 22-60, 126-131.) 
Varhaisen kreikkalaisen runon eläimellisyyttä onkin etsittävä pintaa syvemmältä, tapahtumien ja henkilöhahmojen sijasta ennen kaikkea kielen tasolta. Arkaainen runous on täynnä eläinmetaforia. Esimerkiksi Homeroksen leijoniin, villikarjuihin, pesäänsä puolustaviin myrkkykäärmeisiin ja mylviviin härkiin vertautuvat soturit ja Sapfon (n. 630-570 eKr.) "suloisenkatkeraa, kesytöntä petoa" (Sapfo 1969, 114) tutkivat rakkausrunot on niin kyllästetty eläinmaailmaan viittaavin metaforin, ettemme edes kiinnitä siihen erityistä huomiota (Steiner 2005, 40-41). Homeros kuvaa myös lajienvälistä kumppanuutta unohtumattomalla ja syvästi emotionaalisella tavalla.

Iliaan 17. laulussa Akhilleuksen kuolemattomat hevoset Balios ja Ksanthos surevat kuollutta Patroklosta vuodattamalla kuumia kyyneliä ja herkistävät säliiin itse Zeuksen (Homeros, Il. 17, 425-459), ja myöhemmin Ksanthos puhkeaa jopa puhumaan akhaijien kieltä Akhilleuksen solvattua hevosiaan Patrokloksen ruumiin jättämisestä sotatantereelle (Homeros, Il. 19, 397-417). Odysseiassa vastaava juonellisesti käänteentekevä ja kaikkina aikoina tunteita herättänyt kohtaus on kotiin palaavan Odysseuksen ja vanhan Argos-koiran kohtaaminen Ithakassa:

Heidän näin puhellessaan nosti lähellä makaileva koira päätään ja korviaan, se oli Argos, sisukkaan Odysseuksen koira jonka hän itse oli kasvattanut [...] Mutta nyt se makasi hyljättynä, isäntäänsä kaivaten kaikessa liassa mitä muulit ja lehmät olivat tehneet portin eteen [...] Siinä Argos makasi karva kirppuja täynnä mutta heti kun se tajusi Odysseuksen, se heilutti häntäänsä ja laski korvansa alas, mutta ei jaksanut lähestyä isäntäänsä. Odysseus käänsi katseensa pois ja häntä itketti mutta kätkien kyyneleensä Eumaiokselta hän sanoi nopeasti: "Eumaios, tuo liassa makaava koira on oikea ihme!" (Homeros 2012, 231; Odysseian 17. laulu, säkeet 290-306.)

Sikopaimen Eumaios, joka ei vielä tässä vaiheessa tiedä kenen kanssa keskustelee, kertoo koiran pentuajasta suuren miehen kasvattina ja nykyisestä alennustilasta heitteille jätettynä vanhuksena. Tämän jälkeen runon kertojaääni siirtyy Eumaioksen kanssa sisään Odysseuksen taloon. Koira ja pitkältä matkalta palannut mies jäävät hetkeksi kahden. Runoilija paljastaa vain, että kaksikymmentä vuotta omaa ihmistään odottaneen Argoksen vie "kuolon tumma osa" (Homeros, Od. 17, 326). Kaikki muu jää sanojen ulottumattomiin - kohtauksen emotionaalinen intensiteetti on kääntäen verrannollinen siihen hiljaisuuteen, jonka vallassa kumppanukset tunnistavat toisensa ja ovat hetken toisilleen läsnä.

Arkaaisen runouden ilmentämän eläinajattelun tavoittamiseksi on kuitenkin mentävä vielä metaforia ja henkilösuhteita syvemmälle, sanoihin itseensä. Kuten Francis Wolff toteaa, kreikan eläintä merkitsevä sana, 乌̧̣̄ov, (sananmukaisesti "elävä") kattaa myös ihmisen ja jumalat (Wolff 1997, 157-158; vrt. esim. Platon, Euthydemos 302d-e; Aristoteles,

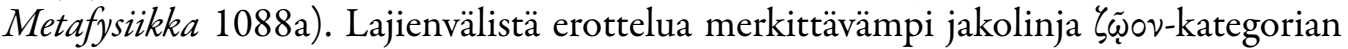
sisällä kulkee kuolevaisten ja kuolemattomien välillä - ja kuolemattomien joukkoon kuuluu myös olentoja, jotka me miellämme eläimiksi, esimerkkinä yllä mainitut Akhilleuksen lahjaksi saamat hevoset Ksanthos ja Bailos. Kuten edellä on nähty, Empedokleen radikaalein ajatus oli itse asiassa tämän jaon kyseenalaistaminen. 
Sellaista kategoriaa, jolla olisi viitattu vain eläviin ja kuoleviin "eläimiin" meidän tuntemassamme merkityksessä, rajaamalla ihmiset ja jumalat kategorian ulkopuolelle, ei ollut kielessä olemassa. Kielen tasolla ihminen on yksi kuolevaisten "heimo" (fyle) muiden joukossa. (Wolff 1997, 157-166; Steiner 2005, 38-39.) Ehkei siis olekaan yllättävää, että mahdollisuus ylittää lajienvälinen raja (taas meidän tuntemassamme merkityksessä), tulla toiseksi ja kokea toisin, tulee monin tavoin esiin arkaaisessa runoudessa, mytologiassa ja uskonnollisissa rituaaleissa.

\section{Alkmanin hevostytöt}

Mitä lajienvälisten rajojen ylittäminen tarkoittaa käytännössä? Otan esimerkin Alkmanilta, 600-luvulla eKr. Spartassa eläneeltä kuorolyyrikolta. Hänen runouttaan tunnetaan enää ainoastaan fragmentteina, ja seuraava ote (säkeet 39-59) on laajimmasta säilyneestä kokonaisuudesta; runosta on säilynyt arviolta noin puolet, 100 säettä, näistäkin osa vaillinnaisesti papyruksen reunan kulumisen vuoksi. Kyse on rituaalisessa yhteydessä esitetystä ns. neitolaulusta, jossa alun kadonneen myyttiosan jälkeen tyttökuoro ylistää Agido- ja Hagesikhora-nimisiä neitoja, mahdollisesti esilaulajiaan, ja kuvailee samanaikaisesti suorittamaansa (tai mainittujen neitojen suorittamaa) aamuöistä rituaalia jumalattarelleen.

... minä laulan

Agidon valoa: hänet näen

kuin auringon, sen jonka Agido

todistajaksemme kutsuu esiin.

Mutta ylistää tai moittia häntä ei

kuulu kuoronjohtajamme salli,

ei minun eikä meidän; hän itse

erottuu joukosta niin kuin

laidunkarjan keskellä voitokas

vahva hevonen, helähtäväkenkäinen

ja kivenalisten unien oma.

Etkö muka näe? Sotaratsu on

enetialainen, mutta sisareni

Hagesikhoran harja kukkii

puhdasta kultaa, hänen

kasvonsa ovat hopeaiset.

Miksi puhun siitä mikä on

ilmiselvää, Hagesikhora itse?

Ja toisena ylväs Agido niin kuin

skyyttihevonen lyydialaisen jäljessä;

[...] 


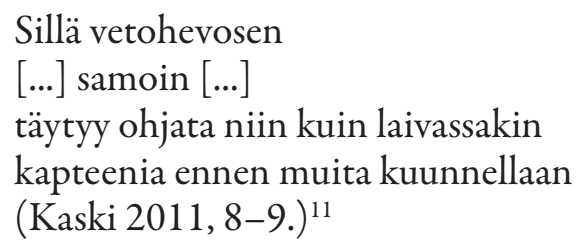

Runo on mitä ilmeisimmin nuorten tyttöjen suorittaman joko vuodenaikaiskiertoon tai ikäkauteen (tai luultavasti molempiin) liittyvän rituaalin eräänlainen käsikirjoitus, tarkemmin sanottuna sen "soundtrack" ja koreografia. Tyttöjen kuoro on sitä laulaessaan suorittanut tiettyjä rituaalisia toimia, joita on itse runon, muiden vastaavien runojen, vaasimaalausten, antiikin kommentaattoreiden ja muun kontekstitietouden perusteella pyritty rekonstruoimaan ja tulkitsemaan (esim. Calame 2001; Ferrari 2008; Burkert 1983, 151). Hevosmetaforien ketju liittyy yhtäältä tyttöjen ulkonäköön, toisaalta heidän liikkeisiinsä: tanssiin, rituaalin elekieleen, luultavasti juoksuaskeliin. Arkaaisen ajan Spartassa ja ilmeisesti muuallakin Kreikassa juoksukilpailut kuuluivat tyttöjen kasvatukseen, ja niihin liittyy niin uskonnollisia kuin seksuaalikasvatukseen tähtääviä aspekteja.

Lainaamassani otteessa Agido ja Hagesikhora osallistuvat rituaaliseen juoksukilpaan - kyse voi tietysti olla vain metaforasta, mutta luultavasti juoksukilpa käytiin myös rituaalin todellisuudessa. Agidoa ("skyyttihevosta") verrataan Hagesikhoraan ("lyydialaiseen"); lyydialainen hevonen on siis ilmeisesti vielä skyyttiläistäkin parempi juoksija. Merkitystä rakennetaan runossa mainittujen hevosten tyypillisen värityksen, kenties muidenkin rotuominaisuuksien varaan. Adrianmeren pohjukkaan sijoitettu Enetia oli hevosistaan kuulu ainakin myöhemmin antiikin aikana, viimeistään 400-luvulta eKr. eteenpäin, joten määre ei luultavasti ole satunnainen. Runoa on tulkittu niin, että joko eneettien hevoset olivat tyypillisesti tietynvärisiä, tai sitten eneetteihin kansana tai heidän pukeutumiseensa yhdistettiin tietty väri, esimerkiksi musta (Ferrari 2008, 75-76, 95). Skyytteihin puolestaan liitettiin paitsi symbioottisia piirteitä saanut hevoskulttuuri (satulassa nukkuminen jne.), myös punatukkaisuus; Lyydiaan taas yhdistyy satumainen kultarikkaus ja sitä kautta kullanhohtoinen väri (Ferrari 2008, 95-96; vrt. myös esim. Sapfo 1969, 17, 127). Tyttöjen ulkonäköä, olemusta, liikkeitä ja hiusten tai vaatetuksen värïä voidaan siis runossa kuvata hevosten ominaisuuksien kautta.

Runossa puhutaan myös Hagesikhoran "harjasta" - sana $\chi \alpha i \tau \alpha$ viittaa Homeroksella sekä ihmisen hiuksiin että hevosen harjaan. On mahdotonta tietää, onko sana Alkmanilla jo eriytynyt merkitsemään selkeämmin vain hevosen harjaa ja korostaako metafora siten tyttöjen vertaamista hevosiin muutenkin, vai onko sana aikalaiskuulijoiden korvissa viitannut neutraalisti myös ihmisen hiuksiin. Tämä olisi yksi esimerkki edellä tarkastellusta lajienvälisestä yhteydestä "eläin"-kategorian sisällä. Joka tapauksessa keskeinen merkitys on nimenomaan vapaana hulmuava, kenties juoksukilpailun tiimellyksessä liehuva tukka.

Hevosiin liittyy kuitenkin muitakin merkityksiä kuin niiden kauneus tai juoksunopeus. Tyttöjen ikäkausirituaaleja tutkineen Claude Calamen mukaan hevosen kesyttäminen on kreikkalaisessa runoudessa keskeinen lapsenkasvatuksen metafora, ja tammavarsan kesyttäminen liittyy sekä lapsen enkulturaatioon että avioliittoon, joka oli tytön kasvatuksen tavoite ja päätepiste (Calame 2001, 118-119, 238-239). Eikä hevosenkesytys metaforana rajoitu vain tyttöihin: esimerkiksi spartalaisten poikien ns. 
agele-kasvatusjärjestelmä verbalisoitiin hevosten koulutukseen ja varusteisiin liittyvän termistön avulla (Calame 2001, 215).

Mytologiassa hevoset ja vaununajo liittyvät usein avioliiton solmimisen teemoihin ja seksuaalisuuteen (Calame 2001, 238-244; Nagy 1996,43-45; Sergent 1997, 473-480). Monet näistä myyttiaiheista ovat varhaisia ja laajalle levinneitä, mutta kaikuja hevosmetaforan kytköksestä avioliiton ja seksuaalisuuden teemoihin voidaan tavoittaa vielä esimerkiksi hellenistisestä rakkausromaanista 100 -luvulta jKr. Toisaalta taivaankappaleet on myyttisessä mielikuvastossa mielletty hevosten vetäminä tai kantamina henkilöityminä, jotka seuraavat toinen toistaan taivaan halki määrättyä polkua, käyvät siis eräänlaista kosmista juoksukilpaa (esim. Ferrari 2008, 65-66). Ajatus toisiaan kilpaa seuraavista, hevosten kuljettamista taivaankappaleista on myyttisenä mielikuvana huomionarvoinen myös Alkmanin runon ja siihen liittyvän rituaalin tulkinnan kannalta, sillä runon säilyneissäkin osissa on myös kosmisia, vuorokauden- ja vuodenaikaan liittyviä viittauksia (säkeet 60-64, tarkemmin ks. Kaski 2011, 8-12, 20-22). Kuva hevosiksi mieltyvien tyttöjen kosmisesta juoksukilvasta sitoo yhteen teoriat runosta yhtältä ikäkausi-initiaation (kuorolaisten naimaikä), toisaalta kalendaaririitin (kyntökauden alku, syksyn ja talven taite) ilmentäjänä. Runossa ja sen kontekstina toimivassa rituaalissa mitä luultavimmin yhdistyvät molemmat.

Vaikka runous kreikankielisessä maailmassa jo arkaaisella ajalla oli yksilöllisten, nimeltä tunnettujen runoilijoiden kirjoittamaa sanataidetta, sidos kollektiiviseen, myyttiseen merkityksenmuodostukseen oli vielä vahva. Siksi arkaaista runoutta on vaikea ymmärtää ilman laajaa kontekstitietoutta runon esitystilanteista, esittäjistä, runouteen erottamattomasti kuuluvasta musiikista ja (etenkin kuorolyriikan kohdalla) tanssista. Suurin osa tästä kontekstitietoudesta on meiltä kateissa, tai monen rekonstruktio- ja tulkintamutkan takana. Siinä missä antiikin kreikkalaisen kirjallisuuden ja sen kontekstien historia on välillä ihmeenomaisenkin säilymisen ja toisaalta armottoman katoamisen ja kadottamisen historiaa, kreikkalais-klassisen mytologian ote eurooppalaisesta kulttuurista on ollut niin vahva, että aineistoa ihmisen eläinsuhteen tutkimiseen on mytologisten teemojen kautta säilynyt enemmän kuin filosofeilta ja runoilijoilta yhteensä.

\section{JUMALA ELÄIMENÄ}

Kreikkalainen mytologia on täynnä kiinnostavia muodonmuutoksia ja hahmoja, joiden lajia on vaikea tarkkaan määritellä. Esimerkiksi kentaurit ovat huomionarvoinen ryhmä yhtälı̈ä hevosiin liittyvän seksuaali- ja avioliittometaforiikan kannalta, toisaalta siksi, että kentaurien ilmentämä villin luonnon ja inhimillisen kulttuurin vastakkainasettelu liittyy oleellisesti myös kysymykseen antiikin kreikkalaisen kulttuurin eläinsuhteista. Koska tila on rajallinen ja koska olen itse kiinnostunut erityisesti jumalan ja eläimen suhteesta kreikkalaisessa ajattelussa edellä esiin tulleen ל̧̣̄ov-kategorian sisällä, sivuutan tässä kentaurit, seireenit, sfinksit, gorgot, griipit ja muut lajienvälisyyden kannalta mielenkiintoiset hahmot ja tarkastelen vain yhtä, joskin korkeimmalla mahdollisella taholla toimivaa esimerkkiä. 
Zeuksen muodonmuutokset häräksi ja joutseneksi tuottivat kreikkalaiseen ja myöhempään maailmanjärjestykseen lähtemättömän jäljen. Tarina Zeus-härän ryöstämästä foinikialaisesta Europasta, joka synnytti Zeukselle vaihtelevan määrän jälkikasvua, ${ }^{12}$ on ilmeisesti alkuaan kreetalainen ja liittyy tavalla tai toisella minolaisen Kreetan härkäkulttiin. Arkaaisella kaudella se oli jo yleiskreikkalaista mytologista pääomaa, ja 400-luvulla eKr. Herodotos rationalisoi myytin kertomukseksi eurooppalaisten (kreikkalaisten) ja aasialaisten (persialaisten) välisen vihanpidon juurista (Herodotos, Historiateos 1, 2-4). Herodotos myös liittää kreikkalaisen aakkoskirjoituksen synnyn Europan ryöstöön: sisartaan etsivä Kadmos toi muassaan Kreikkaan foinikialaiset aakkoset sekä perusti samalla Theeban kaupungin (Herodotos, Historiateos 5, 58) ja kuningashuoneen, josta myöhemmin tuli klassisen tragedian keskipiste, Kadmos oli nimittäin Oidipuksen isänisänisänisä. Nykytutkimus tukee Herodotosta: kreikkalaiset saivat aakkoskirjoituksen foinikialaisilta, ja vokaalien lisääminen aakkosiin kreikankielisellä alueella loi järjestelmän, joka mahdollisti kirjoitustaidon laajamittaisen omaksumisen ja ennennäkemättömän kulttuurivallankumouksen (Horrocks 2010, 13; Ong 1967, 33-47; ks. myös Havelock 1963, joka kokonaisuudessaan on syvällinen analyysi kirjoitustaidon sisäistämisen lähtökohdista, vaiheista ja seurauksista klassisen ajan Kreikassa).

Toinen merkittäviä jälkiseuraamuksia tuottanut eläimellinen muodonmuutos tapahtui Zeuksen iskettyä silmänsä Ledaan, Spartan myyttisen kuninkaan Tyndareuksen puolisoon. Joutseneksi muuntautuneen Zeuksen lähentelyn seurauksena Leda muni kaksi munaa, joista kuoriutuivat kaksosveljet Kastor ja Polydeukes sekä tyttäret Klytaimnestra ja Helena, kaunein kaikista ihmisistä. Helenaa ja useimmiten Polydeukesta pidettiin Zeuksen lapsina, Klytaimnestra ja Kastor (toisinaan myös Polydeukes) luettiin kuolevaisen Tyndareuksen jälkeläisiksi.

Niin Helenalla kuin hänen veljillään oli Spartan uskonnollisessa kultissa keskeinen rooli (Burkert 2003, 203-213; Calame 2001, 195; Ferrari 2005, 22). Helenaa on mm. ehdotettu edellä käsitellyn Alkmanin runon ja rituaalin kohteeksi (Calame 1983, 343), salaperäiseksi Aamun jumalattareksi, jota runo ei varsinaisesti nimeä. Vakiintuneen homeerisen myytin mukaan Agamemnonin veli Menelaos sai Helenan ja Spartan kuninkuuden - ja historian kenties kuuluisimman petetyn aviomiehen osan. Helenan karattua troijalaisen Pariksen matkaan Menelaos kokosi veljensä Agamemnonin kanssa sotajoukon, joka pyyhälsi Peloponnesokselta Egeanmeren yli Troijaan kostoretkelle. Myyttisen Troijan sodan alkusyynä Helena, joutsen-Zeuksen lapsi, kasvoi spartalaista paikalliskulttia verrattomasti suuremmaksi hahmoksi viimeistään 500-luvulta eKr. eteenpäin, kun Homeroksen Ilias sai vakiintuneen muotonsa ja levisi ympäri helleenistä maailmaa.

Zeuksen toimet härkänä ja joutsenena muuttivat siis merkittävästi kreikkalaista maailmaa mytologisen mielikuvaston tasolla. Niiden seurauksena katsottiin syntyneen kreikkalainen kirjoitustaito, niiden seurauksena kokonainen maanosa löysi paikkansa ja nimensä, ja niiden seurauksena syttyi Troijan sota, kaikkien eeppisten taisteluiden arkkityyppi. Syntyi epiikkaa, jota kreikkalaiset itse ja monet eurooppalaiset myöhemmin pitivät kirjallisen kulttuurinsa suurimpana saavutuksena. On vaikea sanoa, missä määrin Europan ryöstötarinan tai Helenan toisenlajiset juuret askarruttivat antiikin ajan kreikkalaisia, mutta asiaa sietäisi tutkia. Toinen kiinnostava jatkopohdinnan aihe, johon 
en tartu tässä, olisi kartoittaa Zeuksen viettelystrategioita tarkemmin. Herää nimittäin kysymys, muuntautuuko Zeus eläimeksi päästäkseen lähelle haluamiaan kuolevaisia naisia ilman pakottamista ja väkivaltaa, siis välttyäkseen suoranaisesti raiskaamasta näitä - Ledan ja Europan tapauksessahan nainen itse tuntuu ojentavan kätensä syleilläkseen joutsenta ja koskettaakseen valkoisen härän turpaa - ja edelleen, millaisena siis näyttäytyy myyttisten ihmisnaisten suhde toisenlajisiin eläimiin, seksuaalisuuteen ja potentiaalisiin seksuaalisiin uhkiin.

Otan Zeuksen viettelyretkistä vielä yhden esimerkin, jossa eläintematiikka on erityisen keskeinen, monimutkainen ja kiinnostava. Artemiksen ja Apollonin äiti Leto oli titaani, eräänlainen puolijumala, tai edellisen jumalsukupolven tai ihmisen edellisen kehitysvaiheen edustaja. Itse viettelytapahtumasta ei ole muuta tietoa kuin myöhäinen latinankielinen lähde (300-400-luvun taitteessa elänyt Vergiliusta kommentoinut grammaatikko Servius), jonka mukaan Zeus aktin ajaksi muutti joko Leton, itsensä tai molemmat viiriäisiksi. Jälkikasvun edesottamusten valossa viiriäisversio tosin on outo ja pohjautunee kansanetymologiaan ja/tai sekaannukseen Leton sisaren Asterian kohtalon kanssa, mutta sitä huomionarvoisempi on liitosta syntynyt jumalkaksikko, Artemis ja Apollon, ja heidän yhteytensä suuriin villieläimiin, erityisesti karhuun (arktos) ja suteen (lykos).

Toinen myöhäinen lähde, 100- tai 200-luvulla jKr. eläneen kreikkalaisen Antonius Liberaliksen muodonmuutoskokoelma, kertoo Leton vaeltaneen jumalkaksosten syntymän jälkeen Anatolian lounaisosaan. Paikalliset paimenet kielsivät häneltä juomaveden, jolloin ystävällinen susilauma otti huolehtiakseen tuoreesta äidistä ja johdatti hänet lapsineen Ksanthos-joelle. Leto pyhitti joen pojalleen Apollonille ja nimesi maan Lyykiaksi, "Susimaaksi". Leton, Artemiksen ja Apollonin kolmoiskultti oli hellenisoidun Lyykian tärkein kultti, ja susitarina on ehkä yhdistetty Letoon kreikankielisen kansanetymologian perusteella vasta hellenistisellä ajalla; maan nimi palautunee todellisuudessa alueen pronssikautiseen, heetinkieliseen Lukka-nimeen.

Manner-Kreikan puolella Leto yhdistyy susiin kuitenkin myös paljon varhaisemmassa arkadialaisessa perinteessä, joskin vain välillisesti poikansa Apollonin ja tämän isän kautta. Arkadian Lykaion-vuorelta, Peloponnesoksen keskiosista, tunnetaan ikivanha Lykaia-kultti, jonka arkeologiset jäljet ulottuvat neljän vuosituhannen päähän. Klassisena aikana vuorella palvottiin Zeus Lykaiosta ja järjestettiin Lykaia-festivaaleja. Toisaalta esimerkiksi matkakirjailija Pausaniaksen (n. 110-180 jKr.) havainnoista voidaan päätellä, että monin paikoin pohjoista Peloponnesosta myös Apollon yhdistettiin suteen; kyseessä lienee vanha susiin liittyvä paikallisperinne, jonka olympolainen jumalperhe oli sulauttanut itseensä. Lykaia-kultin klassisessa perustamismyytissä Arkadian kuningas Lykaon syöttää poikansa Zeukselle ja saa rangaistuksena suden hahmon. Myytistä on lukuisia versioita, mutta kaikkia yhdistää jonkinlainen kannibalistinen lihansyöntirikos ja muodonmuutos sudeksi. (Ks. esim. Burkert 1983, 84-93; Cole 2004, 64-65, 188.) Erään version mukaan syötäväksi tarjottu uhri oli Arkas, Lykaonin tyttären Kalliston poika.

Kalliston ja hänen poikansa Arkaksen kautta päädymme Artemikseen ja suomalaisesta näkökulmasta hyvin kiinnostavaan karhukulttiin. Jumalattarena ja kultin kohteena Artemis on monitahoinen hahmo: hän on potnia theron, eläinten valtiatar, neitseellinen metsästäjä sekä raskauden, synnytyksen ja lapsuuden, erityisesti tyttölasten suojelija. 
Tavalla tai toisella Artemis yleensä liittyy villin ja kesyn, eläimellisyyden ja naiseksi/ ihmiseksi kasvamisen tematiikkaan. (Esim. Calame 2001, 118-119, 238-239; Burkert 2003, 149-151.) Kallisto ("kaunein") on toisaalta Artemikseen sulautuva epiteetti, toisaalta arkadialaisessa perinteessä Artemiksen nymfi, joka Zeuksen viettelemänä tulee raskaaksi ja jonka Artemis muuttaa karhuksi joko raivostuttuaan itse tai suojellakseen nymfiään Heran raivolta. Raiskatun Kalliston isä Lykaon kostaa Zeukselle tyttärensä häpäisyn yrittämällä syöttää (karhun)poika Arkaksen jumalalle, kuten edellä on nähty. Kallistoon ja Arkakseen liittyvässä arkadialaisessa tarinastossa on totemistinen vire ja mielenkiintoinen lihansyöntiin ja jumaliin liittyvän taburikoksen teema, jonka kaltaisia kreikkalaisesta mytologiasta löytyy muitakin.

Artemiksen ja karhun läheinen suhde ei kuitenkaan jää tähän. Eräs karhuemo nimittäin adoptoi toisen arkadialaisen Artemikseen liitetyn hahmon, Atalanten, jonka omat vanhemmat olivat hylänneet metsään. Neito omistautuu Artemiksen nymfiksi ja varttuu poikkeuksellisen taitavaksi metsästäjäksi. Halukkaita sulhasia riittää kentaureista ihmissankareihin, mutta Atalanten kesyttää monien kohtalokkaasti epäonnistuneiden yrittäjien jälkeen, rituaalisen juoksukilvan myötä, muuan Hippomenes. ${ }^{13}$ Atalanten myytissä kietoutuvat siis kiinnostavasti toisiinsa Artemiksen arkadialainen karhuaspekti ja yleiskreikkalainen ajatus hevosista seksuaalisuuden ja neidon vaimostatukseen siirtävän riitin metaforana. (Atalanten suhteesta hevosiin ks. erityisesti Sergent 1997, 473-480.)

Kalliston ja Atalanten myytit elävät tarinoina ja taiteen motiiveina, haarautuvat moneen suuntaan ja on kerrottu niin monina erilaisina versioina vuosisatojen kuluessa, että konkreettista linkkiä itse uskonnonharjoitukseen ja sitä kautta perustavanlaatuisiin eläimen ja jumalan suhdetta koskeviin käsityksiin on niiden perusteella vaikea muodostaa. ${ }^{14}$ Jos arkadialaisesta perinteestä onkin vaikea saada otetta varsinaisten rekonstruoitavissa olevien kulttien muodossa, Artemiksen karhukultti on kuitenkin jättänyt itsestään konkreettisen jäljen Ateenan Akropoliille ja attikalaiseen uskonnonharjoitukseen, joka tunnetaan arkadialaista paremmin. Käsittelenkin artikkelini lopuksi Artemis Brauronian kulttiin liittyvää Arkteia-juhlaa esimerkkinä kreikkalaisesta rituaalista, joka koettelee niin lajienvälisiä rajoja kuin vakiintuneita käsityksiämme antiikin kreikkalaisen uskonnon antroposentrisyydestä.

\section{BRAURONIN PIKKUKARHUT JA RITUAALINEN ELÄIMELLISYYS}

Edellä Alkmanin runossa, kuten yleensä kuorolyyrikkojen neitolauluissa, muodostettiin tyttöjen laulu- ja tanssipiiri, kuoroksi suomentuva mutta kohti laajempaa rituaalisen tilan

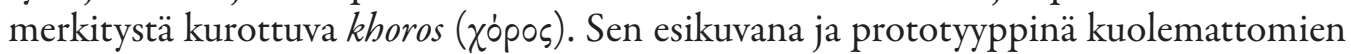
parissa on useimmiten Artemis-jumalattaren johtama khoros. Nimenomaan Artemikseen liittyy Kreikassa lukuisia kultteja, joissa tyttöjen sosialisaatiolla tanssin, musiikin ja urheilun kautta oli keskeinen osa (Lonsdale 1993, 38, 170). Näistä tunnetuin lienee Attikan Brauronissa toimeenpantu Arkteia-juhla.

Arkteiaa on tutkimuksissa kuvattu, pohdittu ja tulkittu monin tavoin (ks. esim. Cole 2004, 195-196, 210-229; Faraone 2003, 43-68; Burkert 2003, 151; Marinatos 2002, 
29-42). Varhaisia kirjallisia lähteitä ovat Ifigeneian myytti tragediarunoilijoilla sekä Aristofaneen Lysistraten maininnat ateenalaisten nuorten naisten koulutuksesta ja ikäkausirituaaleista. Arkteiaan liittyvää arkeologista materiaalia on löydetty sekä Brauronin temppelialueelta Attikan itärannikolta ja muista attikalaisista Artemiksen pyhäköistä että Ateenan Akropoliilta, jonka länsipäässä, heti sisäänkäynnin jälkeen oikealla, sijaitsi eräänlainen Artemis Brauronian ”sivukonttori”. Pyhäkössä säilytettiin mm. Artemis Brauronialle annettuja votiivilahjoja ja niiden luetteloja. Tärkeä lähde ovat myös vaasimaalaukset, erityisesti pienet krateriskos-maljat, joita tyttöjen perheet uhrasivat kultin yhteydessä ja joiden kylkiin on maalattu eri-ikäisiä lapsia ja naisia ilmeisesti Arkteiaan liittyvissä toimissa.

Lähteiden perusteella on voitu päätellä, että Arkteia oli attikalaisten tyttöjen kasvatukseen liittyvä juhla. Millainen yksityiskohdiltaan, minkä ikäisille ja kenelle kaikille tarkoitettu, on jäänyt epäselväksi - mutta rituaalin olennainen tarkoitus lienee ollut tyttöjen kouluttaminen omaan osaansa maailmassa, heidän kasvatuksensa kunniallisten kansalaisten kunnollisiksi kansalaisvaimoiksi. Kulttiin liittyi myös lelujen uhraamista Artemikselle häiden alla sekä vaatteista koostuva kiitosuhri lapsen syntymän jälkeen. Synnytykseen kuolleiden naisten vaatteet sen sijaan uhrattiin Brauronissa Ifigeneialle, jonka Agamemnon, hänen isänsä, joutui myytin mukaan uhraamaan Artemiksen lepyttämiseksi karhuun kohdistuneen taburikoksen jälkeen.

Kiinnitän tässä yhteydessä erityistä huomiota itse verbiin, jolla Brauronissa tapahtuvaa

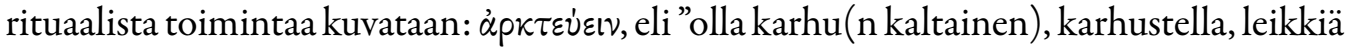
karhua". Tyttölapset, eri arvioiden mukaan viisivuotiaista puberteetti-ikäisiin, viettivät tietyn ajan pyhäkössä Brauronin soisilla takamailla kaukana kaikesta. "Karhustelu" sisälsi ilmeisesti tanssin ja musiikin lisäksi urheilukilpailuja ja/tai rituaalisen kauhun innoittamaa juoksemista (Lonsdale 1993, 174-192).

Arkteia-rituaali muistuttaakin urheiluun ja musiikkiin nojaavaan kreikkalaiseen kasvatukseen keskeisesti kuuluvasta, hyvin kouriintuntuvasta mimeettisyydestä, ${ }^{15}$ jossa ruumiillinen toisena tai toisen kaltaisena olemisen kokemus lienee tukenut sekä itsen rajoja että kykyä niiden ylittämiseen ja toisen (ihmisen tai eläimen, sukupuolen jne.) kohtaamiseen. Tytöt muodostivat rituaalisen tilan, khoroksen, jossa he muuntautuivat mimeettisen jäljittelyn avulla toiseksi niin kokonaisvaltaisella tavalla, että sitä kuvaamaan on tarvittu oma "karhuna olemisen" verbi. "Karhustelun" perimmäinen funktio lienee kurkottaminen pyhää toiseutta, jumalatarta, kenties karhuhahmoista Artemista kohti, ja sitä kautta muodonmuutos lapsesta nuoreksi neidoksi ja avioliittoon valmistautuvaksi "nymfiksi".

Kreikkalaisen tanssin kultilliset juuret on Arkteiaa laajemminkin liitetty eri eläinten mimeettiseen jäljittelyyn (esim. Lawler 1946). Tanssi, musiikki ja urheilu olivat keskeinen osa niin tyttöjen kuin poikien kasvatusta ja koulutusta vielä klassisena aikana. Inhimillisen oppimisprosessin ytimenä siis ajateltiin olevan toisen (lajin) "jäljittely", toisen (lajin) kaltaiseksi tuleminen rituaalin tilassa, toisen (lajin) mukaan ja mukana kokeminen, empatia. 
Liisa Kaski: Ihmisen ja eläimen suhteesta varhaisessa kreikkalaisessa ajattelussa

\section{LOPUKSI}

Koska kreikkalainen aineisto runoudesta kuvataiteeseen, filosofiasta oikeustapauksiin, rituaalikuvauksista kiroustauluihin ja oraakkelilausumiin on valtava, olen joutunut rajaamaan aineistoesimerkkini varsin mielivaltaisesti. Toisaalta artikkelin tarkoituksena ei ole ollut esittää kattavaa kuvaa eläinten asemasta, eläimiin liittyvästä perinteestä tai moraali- ja oikeusajattelusta kreikkalaisessa antiikissa yleensä tai edes tietyllä vuosisadalla tai paikkakunnalla. Pyrkimykseni oli nimenomaan poimia kulttuurikerroksista niitä juonteita, jotka ehkä selittävät, miksi Empedokleen ja Plutarkhoksen edustama filosofinen perinne ei ollutkaan niin kovin radikaalia kuin meidän näkökulmastamme saattaa vaikuttaa - ja jotka kenties syventävät omaa suhdettamme ja kannanottojamme moderniin eläinoikeuskeskusteluun.

Kävin lyhyesti läpi Plutarkhoksen kolmessa eläinaiheisessa tekstissään esittämiä argumentteja eläinten tappamista vastaan. Nostin esiin erityisesti tekstikohtia, joissa Plutarkhos puhuu suhteestamme toisenlajisiin eläimiin vaikeasti käännettävällä mutta tapaoikeuteen palautuvalla dike-termistöllä. Oikeuteen ja oikeudenmukaisuuteen liittyvä sanasto houkutti vertaamaan Plutarkhoksen ajatuksia nykyaikaiseen eläinoikeusfilosofiaan: yhtäläisyyksien avulla pyrin osoittamaan käsitykset eläinoikeuspuheen historiattomuudesta vääriksi, eroja huomioimalla taas toin esiin Plutarkhoksen ajattelun niitä puolia, jotka moderni eläinmyönteinen ajattelu hänestä tukea hakiessaan todennäköisesti sivuuttaa.

Plutarkhoksen teksteistä voidaan tavoittaa lajienvälisen kumppanuuden ja toisilta lajeilta oppimisen eetos. Erityisen kiinnostavana ajatuksena nostin esiin samaheimoisuuden käsitteen, jonka varhainen edeltäjä, ajatus kaikkien eläinten yhteisestä syntyperästä ja kohtalonyhteydestä, löytyy Empedokleen fragmenteista. Myös Empedokles kielsi eläinten tappamisen vetoamalla tapaoikeuteen viittaavaan "kaikkien lakiin"; hänen ajattelussaan eläinten oikeus elämäänsä liittyi myös ihmisen kosmiseen hyvinvointiin ja rakkaudellisuuden ja kiistan ikuiseen vuorotteluun, jossa ihmisen tuli asettua rakkaudellisuuden asialle.

Tarkastelin eläinmyönteisen filosofisen perinteen taustalla vaikuttavaa kulttuuria käsittelemällä arkaaisen runouden tapaa kuvata toisenlajisia eläimiä ja hyödyntää eläinmetaforia. Esimerkkini tosin rajoittuivat lähinnä hevosiin ja koiraan, mutta ainakin näiden eläinten kohdalla kävi selväksi, että toisenlajinen eläin voi runossa olla aktiivinen henkilöhahmo, moraalinen toimija ja ihmisen kumppani. Huomio kreikan "eläin"-sanan merkitysavaruudesta osoittautui tärkeäksi: jos niin ihmiset kuin toisenlajiset eläimet ja jumalat ovat kielellisesti saman kategorian jäseniä, ei ole lopulta mikään ihme, että ihmishahmoisiksi mieltämistämme olympolaisista jumalistakin löytyi hyvin "eläimellisiä" piirteitä ja läheisiä kytköksiä meistä katsottuna toisenlajisiin eläimiin. Esimerkeistä oli pikemminkin runsaudenpula kuin puute.

Kävin läpi myös eläinmetaforien "lihallistumista" rituaaleissa, joissa tavoitellaan metamorfoosin kaltaista tilaa vähintään mielikuvan (Alkmanin runon kuvaama rituaali) mutta myös fyysisen mimeettisen toiminnan kautta (Brauronin Arkteia). Näissä arkaaisen ja klassisen ajan rituaaleissa mitä ilmeisimmin harjoiteltiin (tai harjoitettiin) metamor- 
foosia, toiseksi muuntumista, elämänvaiheesta toiseen siirtymistä, eläinmielikuvien ja mimesiksen avulla. Arkteia-rituaali näyttäytyi malliesimerkkinä siitä, mitä kaikkea eläimen ja jumalan suhde kielessä ja myyteissä voi tuoda mukanaan. Artemis liittyy karhuun useissa eri myyteissä; Atalanten kohdalla herää jopa kysymys siitä, onko metsään hylättyä ihmislasta imettävä karhuemo jumalatar itse. Brauronissa karhustelevilta tytöiltä taas voidaan kysyä, missä oikeastaan menee ihmisen, toisen eläimen ja jumalan raja.

Klassisen ajan kreikkalaiset ihmiset varmasti vastasivat tähän kysymykseen eri tavoin. Heidän kielensä rakenteet, runoutensa ja tietyt uskonnolliset rituaalinsa kuitenkin mahdollistivat samaistumisen toisenlajiseen eläimeen, tämän olemisen tapaan, ruumiilliseen kokemukseen ja perspektiiviin. Empedokleen näkemys kaikkien elävien olentojen perimmäisestä sukuyhteydestä eettisine implikaatioineen pohjautunee tällaiseen samaistumisen kokemukseen - siis empatiaan, jonka ansiosta mimesis on ylipäänsä mahdollista ja johon Plutarkhos myöhemmin vetosi eläinteksteissään.

Nykyaikaisen luonnontieteellisen maailmankuvan kasvattama ihminen ei toki pääse pakoon biologista sukulaisuuttaan muiden lajien kanssa, mutta lajienvälisestä kumppanuudesta, vastavuoroisuudesta ja mahdollisesta työtoveruudesta on uudemman eläinoikeusfilosofian parissa puhuttu toistaiseksi vähän. Itse arvioisin, että yksi merkittävä pohdintasuunta tulevaisuudessa ja käsittelemieni kreikkalaisten ajattelijoiden anti eläinoikeusajattelulle voisi olla juuri tässä. Toinen tämän artikkelin myötä syventynyt käsitykseni on se, että kaikista paikalliskulttuureista, joissa ihminen on väistämättä toiminut vuorovaikutuksessa yhdessä muiden eläinlajien ja luonnonympäristönsä kanssa, on löydettävissä perinteeksi kiteytyneitä kokemuksia myös positiivisesta, tuhoavan sijaan rakentavasta lajienvälisestä vuorovaikutuksesta. Kulttuurintutkijana koen velvollisuudekseni nostaa näitä positiivista eläinsuhdetta vahvistavia perinteitä esiin ja mukaan yhteiskunnalliseen keskusteluun.

\section{VIITTEET}

1 Teksteistä käytetään usein latinankielisiä nimiä (kreikankielinen nimi sulkeissa) De esu

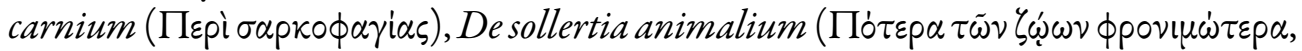

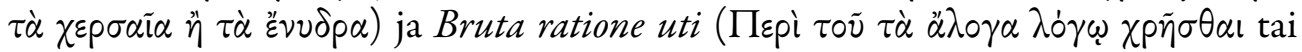

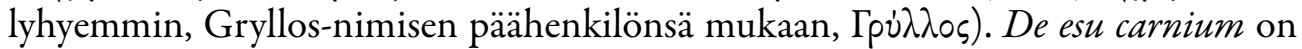
suomennettu nimellä Lihansyönnistä (Plutarkhos 2004). De sollertia animaliumin ja Grylloksen suomennoksia viimeistellään parhaillaan (Plutarkhos, tulossa). Tilan säästämiseksi viittaan jatkossa teksteihin nimilläLihansyönnistä,De sollertia ja Gryllos. Lähdeluettelosta löytyvät myös alkukieliset tekstieditiot.

2 Viittaan Plutarkhoksen tekstikohtiin ns. Stefanos-numerolla, jonka avulla kohta on löydettävissä mistä tahansa alkukielisestä tekstieditiosta ja useimmista käännöksistä.

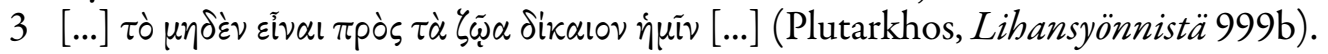

4 Tässä tarkoitettaneen linnustamisen, mahdollisesti myös linnuista ennustamisen taitoa; edellä "toimet maalla ja merellä" viittaavat metsästämiseen ja kalastamiseen.

5 Kydoimos on jonkinlainen personifioitu "sodan melske" (vrt. Homeros, Ilias 18, 535), Kypris taas on rakkauden jumalatar Afroditeen epiteetti tai eräs aspekti; nimi 
palautuu Kyprokseen, jossa Afroditeen katsottiin syntyneen ja/tai josta hänen kulttinsa katsottiin levinneen muille kreikankielisille alueille.

6 Klassinen kreikka ei tee eroa (ihmisen) murhan, tapon ja esimerkiksi uhrieläimen teurastuksen välillä; Empedokleen tässä käyttämä sana фóvo s viittaa yhtälailla kaikkiin näihin tappamisen muotoihin. Oikeusterminä sillä kuitenkin tarkoitettiin (ihmisen) murhaa, tästä syystä pidän perusteltuna kääntää sen tässäkin yhteydessä yksinkertaisesti murhaksi. (LSJ, hakusana фóvos.)

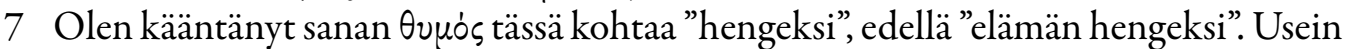
se käännetään sydämeksi tai sieluksi, ja varhaisissa teksteissä sillä tarkoitetaan elämänvoimaa tai -viettiä, usein myös raivon tunnetta tai "sisua", intohimon keskusta, joka saa kaikki eläimet lajista riippumatta taistelemaan henkensä puolesta. Etymologinen tausta muistuttaa suomen "sielua": kyseessä on jonkinlainen henkäys tai liekki, joka elävöittää ruumiin.

8 Viittaan Empedokleen fragmentteihin Wrightin (1995) edition numeroinnin mukaan.

9 Sanaa $\delta \alpha i \mu \omega \nu$ on vaikea kääntää, sillä sen merkityskenttä ulottuu jumalolennoista sieluun ja pahoihin henkiin asti. Empedokleen daimonit pesivät hengen eli edellä käsitellyn thymoksen ja/tai sielun, psykheen, eläväksi tekemässä ruumiissa, siis edellyttävät eläväksi tekevän hengen/sielun, eivät tuota sitä.

10 Auringonvalo on kreikkalaisessa runoudessa yleinen synonyymi elämälle, ja tulkitsen myös Empedokleen säkeen tässä assosioivan elämään yleensä. Vrt. homeerisen runouden lukuisat kuolinkuvaukset, joissa "silmille laskeutuva yö" ja "auringonvalon riistäminen" toimivat kuoleman ja tappamisen eufemismeinä.

11 Suomennoksen pohjana on tuorein Alkman-editio D.L. Pagen ja Malcolm Daviesin (1991) toimittamassa teoksessa Poetarum Melicorum Graecorum Fragmenta. Vol. I: Alcman, Stesichorus, Ibycus. Suomennosratkaisuista ja runon tulkintaan liittyvistä lukuisista kielellisistä ja sisällöllisistä ongelmista tarkemmin ks. Kaski 2011, 9-22.

12 Ainakin Kreetan myyttinen Minos-kunigas, manalan tuomari Rhadamantys ja Anatolian Lyykian asuttajaksi päätynyt Sarpedon mainitaan Zeuksen ja Europan jälkeläisinä.

13 Nimi I $\pi \pi \circ \mu_{\varepsilon} \dot{\varepsilon} \eta$ s merkitsee jotakin sellaista kuin "hevosvoimainen", "hevosenmahtinen", "raivoisa kuin villihevonen".

14 Yksi kiinnostava polku, jota en tässä kykene seuraamaan, olisi pohtia Arkadian ja arkadialaisen folkloren suhdetta yleiskreikkalaiseen kulta-ajan ideaan, joka monissa yhteyksissä palautuu mielikuviin nimenomaan Arkadiasta prototyyppisenä villinä maana, villin äidin (Artemiksen) suojeluksesta nauttivana, inhimillisen historian kuohuilta syrjään jäävänä ja sellaisena jotakin hyvin myyttisenoloista "alkuperäisyyttä” säilövänä alueena. Mielikuva on ainakin kielihistoriallisesti jossain määrin perusteltu: Arkadiassa klassisena aikana puhuttu kielimuoto on todettu erityisen konservatiiviseksi, "mykeneläisiä" eli varhaisimpia tunnettuja kreikan muotoja vaalineeksi murteeksi (Horrocks 2010, 21).

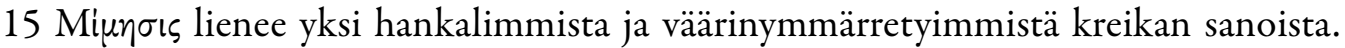
Hermann Koller esitti käänteentekevässä ja sittemmin myös kritisoidussa tutkimuksessaan Die Mimesis in der Antike vuonna 1954, että käsitteenä mimesis liittyy alkujaan tiiviisti juuri tanssiin ja musiikkiin (ks. esim Lonsdale 1993, 32; Havelock 1963, 45 
Liisa Kaski: Ihmisen ja eläimen suhteesta varhaisessa kreikkalaisessa ajattelussa

nootti 22). Havelockin (mts.) mukaan ennen Platonia ja osin vielä hänen aikanaan termi mimesis oli vielä konkreettisesti kiinni toisten ihmisten tai eläinten fyysisessä ja äänellisessä jäljittelyssä, toisen kaltaisena toimimisessa - suomen jäljittely, eläytyminen ja samaistuminen vastannevat tätä paremmin kuin latinalaisperäiset imitaatio ja representaatio, joilla termi esimerkiksi englanniksi yleensä käännetään. Klassisen kreikkalaisen koulutusjärjestelmän ydin, jota Platon kuvaa ja osittain kritisoi Lait ja Valtio -teoksissaan, on mimeettinen khoros, siis tanssivaksi kuoroksi järjestyvä, runoa laulava, perinnettä oppiva, kannatteleva ja välittävä ryhmä.

\section{LÄHTEET JA KIRJALLISUUS}

AALTOLA, ELISA 2006: Animal Individuality: Cultural and Moral Categorisations. Turku: University of Turku.

ARISTOTELES 1990: Metafysiikka. - Teokset 6. Suomentaneet Tuija Jatakari, Kati Näätsaari, Petri Pohjanlehto. Helsinki: Gaudeamus.

- 1997: Retoriikka. - Teokset 9. Suomentaneet Paavo Hohti \& Päivi Myllykoski. Helsinki: Gaudeamus.

BALAUDÉ, JEAN-FRANÇOIS 1997: Parenté du vivant et végétarisme radical. Le "défi" d'Empédocle. - Cassin, B. \& Labarrière, J.-L. (toim.): L'animal dans l'antiquité. Paris: Librairie philosophique J. Vrin.

BURKERT, WALTER 1983: Homo Necans: The Anthropology of Ancient Greek Sacrificial Ritual and Myth. (Homo Necans: Interpretationen Altgriechischer Opferriten und Mythen, 1972.) Translated by Peter Bing. Berkeley: University of California.

- 2003: Greek Religion. (Griechische Religion der archaischen und klassischen Epoche, 1977.) Translated by John Raffan. Cambridge, Mass.: Harvard University Press.

CALAME, CLAUDE 1983: Alcman. Introduction, texte critique, témoignages, traduction et commentaire. Roma: Edizioni dell'Ateneo.

- 2001: Choruses of Young Women in Ancient Greece. Their Morphology, Religious Role, and Social Functions. (Les chors de jeunes filles en Grèce archaïque. Vol. I., 1977.) Translated by Derek Collins \& Janice Orion. Lanham, Boulder, New York \& London: Rowman \& Littlefield Publishers, Inc.

COLE, SUSAN GUETTEL 2004: Landscapes, Gender, and Ritual Space. The Ancient Greek Experience. Berkeley, Los Angeles \& London: University of California Press.

EMPEDOCLES 1995: The Extant Fragments. Edited with Introduction, Commentary, Concordance and New Bibliography by M. R. Wright. London: Bristol Classical Press, Gerald Duckworth \& Co, Ltd. [1981]

FARAONE, CHRISTOPHER A. 2003: Playing the Bear and Fawn for Artemis. Female initiation or substitute sacrifice? - Dodd, David \& Faraone, Christopher A. (toim.): Initiation in Ancient Greek Rituals and Narratives: New Critical Perspectives. London \& New York: Routledge.

FERRARI, GLORIA 2008: Alcman and the Cosmos of Sparta. Chicago \& London: The University of Chicago Press. 
Liisa Kaski: Ihmisen ja eläimen suhteesta varhaisessa kreikkalaisessa ajattelussa

HADZISTELIOU PRICE, THEODORA 1979: Hero Cult in the 'Age of Homer' and Earlier. - Bowersock, Glen W., Burkert, Walter \& Putnam, Michael C.J. (toim.): Arktouros. Hellenic Studies presented to Bernard M.W. Knox. Berlin \& New York: Walter de Gruyter.

HAVELOCK, ERIC A. 1963: Preface to Plato. Cambridge, Mass. \& London: The Belknap Press of Harvard University Press.

HERODOTOS 1907-1910: Historiateos. 1-3. Suomentanut Edvard Rein. Porvoo: WSOY.

HERODOTUS 1993: Historiae. Vol. I-II. Edited by K. Hude. Third Edition. Oxford: Oxford University Press.

HOMER 1902: Homeri opera vol. 1-2. Edited by D. B. Monro \& T. W. Allen. Oxford: Oxford University Press.

- 1917: Homeri opera vol. 3-4. Edited by T. W. Allen. Oxford: Oxford University Press. HOMEROS 1919: Ilias. Suomentanut Otto Manninen. Porvoo: WSOY.

- 2012: Odysseia. Suomentanut Pentti Saarikoski. Helsinki: Otava. [1972]

HORROCKS, GEOFFREY 2010: Greek. A History of the Language and Its Speakers. Chichester: Wiley-Blackwell. [1997]

KASKI, LIISA 2011: Alkman: 1. Partheneion. Kandidaatintutkielma. Helsinki: Helsingin yliopisto, Maailman kulttuurien laitos.

LAWLER, LILLIAN B. 1946: Pindar and Some Animal Dances. - Classical Philology 41(3).

LONSDALE, STEVEN H. 1993: Dance and Ritual Play in Greek Religion. Baltimore \& London: The Johns Hopkins University Press.

LSJ = Liddell-Scott-Jones: A Greek-English Lexicon [online]. < http://www.tlg.uci. $\mathrm{edu} / \mathrm{lsj} />$ [9.4.2013.]

MARINATOS, NANNO 2002: The Arkteia and the Gradual Transformation of the Maiden into a Woman. - Gentili, Bruno \& Perusino, Franca (toim.): Le orse di Brauron: un rituale di iniziazione femminile nel santuario di Artemide. Pisa: Edizioni ETS.

NAGY, GREGORY 1995: An Evolutionary Model for the Making of Homeric Poetry: Comparative Perspectives. - Cartes, Jane B. \& Morris, Sarah P. (toim.): The Ages of Homer. Austin: University of Texas Press.

- 1996: Phaethon, Sappho's Phaon, and the White Rocks of Leukas: "Reading" the Symbols of Greek Lyric. - Greene, Ellen (toim.): Reading Sappho. Contemporary Approaches. Berkeley, Los Angeles \& London: University of California Press.

ONG, WALTER J. 1967: The Presence of the Word. Some Prolegomena for Cultural and Religious History. New Haven \& London: Yale University Press.

PAGE, D. L. \& DAVIES, MALCOLM (toim.) 1991: Poetarum Melicorum Graecorum Fragmenta. Vol. I: Alcman, Stesichorus, Ibycus. Oxford: Oxford University Press.

PLATON 1999: Euthydemos. - Teokset 2. Suomentanut Marianna Tyni. Toinen painos. Helsinki: Otava.

PLUTARCHUS 1895: Moralia. Vol. 6. Recognovit Gregorius N. Bernardakis. Leipzig: B.G. Teubner. 
Liisa Kaski: Ihmisen ja eläimen suhteesta varhaisessa kreikkalaisessa ajattelussa

PLUTARCO 1999: Il Cibarsi di Carne. Introduzione, testo critico, traduzione e commento a cura di Lionelle Inglese \& Giuseppina Santese. Napoli: M. D’Auria.

PLUTARKHOS 2004: Lihansyönnistä/Om att äta kött. Kääntäneet Tua Korhonen, Antti J. Niemi ja Pia Åberg. Helsinki: Summa.

— De sollertia. - Plutarkhos: Gryllos. Maa-ja merieläinten älykkyydestä. Kaksi dialogia Plutarkhoksen Moralia-kirjoituskokoelmasta. Suomentaneet Tua Korhonen ja Liisa Kaski. Tulossa.

- Gryllos. - Plutarkhos: Gryllos. Maa- ja merieläinten älykkyydestä. Kaksi dialogia Plutarkhoksen Moralia-kirjoituskokoelmasta. Suomentaneet Tua Korhonen ja Liisa Kaski. Tulossa.

PLUTARQUE 2012: Oeuvres morales, XIV1: Traite 63 - L'Intelligence des animaux. Texte établi et traduit par Jean Bouffartigue. Paris: Les Belles Lettres.

REGAN, TOM 2001: Defending Animal Rights. Urbana \& Chicago: University of Illinois Press.

SAPFO 1969: Iltatähti, bäälaulu. Suomentanut Pentti Saarikoski. Helsinki: Otava.

SERGENT, BERNARD 1997: Pélops et Atalante, ou de quelques manières d'être du cheval. - Cassin, B. \& Labarrière, J.-L. (toim.): L'animal dans l'antiquité. Paris: Librairie philosophique J. Vrin.

SINGER, PETER 1990: Oikeutta eläimille. (Animal Liberation, 1975.) Suomentanut Helena Tengvall. Porvoo, Helsinki \& Juva: WSOY.

SORABJI, RICHARD 1993: Animal Minds and Human Morals: The Origins of the Western Debate. Ithaca: Cornell University Press.

STEINER, GARY 2005: Anthropocentrism and its Discontents: The Moral Status of Animals in the History of Western Philosophy. Pittsburgh: University of Pittsburgh Press.

TEODORSSON, SVEN-TAGE 2007: Introduktion. - Plutarchos: Djurens rätt och vegetarism. Fyra skrifter ur Moralia. Sävedalen: Paul Åströms förlag.

WOLFF, FRANCIS 1997: L'animal et le dieu: deux modèles pour l'homme. Remarques pouvant servir à comprendre l'invention de l'animal. - Cassin, B. \& Labarrière, J.-L. (toim.): L'animal dans l'antiquité. Paris: Librairie philosophique J. Vrin.

WRIGHT, M. R. 1995: Introduction. - Empedocles 1995: The Extant Fragments. Edited with Introduction, Commentary, Concordance and New Bibliography by M. R. Wright. London: Bristol Classical Press, Gerald Duckworth \& Co, Ltd.

Filosofian maisteri Liisa Kaski on folkloristi, kääntäjä ja klassisen kreikan opiskelija Helsingin yliopistossa. 